\title{
The Uses of Cempaka Wood (Magnolia spp) by the Community in Rumoong Atas Village North Sulawesi, Indonesia and Its Environmental Impact
}

\author{
Irawan Arif ${ }^{1,4,1}$, Kismartini ${ }^{2}$, Hidayat Jafron Wasiq ${ }^{3}$, Abdulah Lutfy ${ }^{3}$, Suryaningsih Rahma ${ }^{4}$, \\ Arini Diah Irawati Dwi ${ }^{4}$ \\ ${ }^{1}$ Master Program of Environmental Science, Universitas Diponegoro, Semarang - Indonesia \\ ${ }^{2}$ Department of Public Administration, Universitas Diponegoro, Semarang-Indonesia \\ ${ }^{3}$ Department of Biology, Faculty of Mathematics and Science, Universitas Diponegoro, Semarang - \\ Indonesia \\ ${ }^{3}$ Forest Research and Development Center, Ministry of Environment and Forestry, Bogor - Indonesia \\ ${ }^{4}$ Enviroment and Forestry Research and Development Institute of Manado - Indonesia
}

\begin{abstract}
The uses of cempaka wood to satisfy the demand in constructing houses and household furniture is considered as environmental-friendly doings which can reinforce the efforts of preventing global warming. Cempaka is commonly used by the people in North Sulawesi. This study aims to discover the use of cempaka wood in Rumoong Atas Village, North Sulawesi and its environmental impact. The methods employed are descriptive method based on the interview results from the participants in Rumoong Atas Village and field surveys. The findings indicate that there are various usages of cempaka wood in the village. The villagers prefer cempaka woods because of hereditary uses and the level of cultural historical attachment, excellent timber quality and texture, and the availability. These diverse functions contain implications for abundant existence of cempaka plants around Rumoong Atas Village. The survival of cempaka plants must be maintained and developed continuously because of their varied functions in Rumoong Atas area. The enhancement of these plants by the public of Rumoong Atas is expected to preserve the existence of natural forests in North Sulawesi which have been declining in both quality and quantity and deliver significant influence towards additional width of critical areas.
\end{abstract}

\section{Introduction}

The control of carbon emission is a matter that must be realized to achieve sustainable development purposes and resolve the global warming issue [1]. Address that the carbon emission increases each year unremittingly as the data records global carbon emission in 2018 from fossil fuel elevated approximately $2.7 \%$. Similarly, Intergovernmental Panel on

\footnotetext{
* Corresponding author: arif net23@yahoo.com
} 
Climate Change (IPCC) states that from 1900 - 2005 there was an increase of 0.15 o C until $0.3 \mathrm{o} \mathrm{C}$ in the earth temperature, and it was estimated to have a constant growth of $1.6 \mathrm{o} \mathrm{C}-$ $4.20 \mathrm{C}$ until the year of 2050 or $2070[2,3]$.

One implementable action to resolve the global warming issue is to prioritize environmentally-friendly aspects in satisfying human demands. Mention that eco-friendly technologies emphasize functioning local materials or reducing the excessive material uses [4]. The timber utilization expansion to achieve daily necessities has been counted as one of the actions. Furthermore, it states that nearly $50 \%$ of the woods consisting of carbon and energy consumption processes in log manufacturing produce lower emissions than plastic, cement, and steel. Woods as building supplies are reflected as attaining fewer impacts from water and air contamination, greenhouse effect, and solid waste compared to concrete and steel $[5,6]$. Globally, concrete contributes two-thirds of total energy consumption in nonmetal mineral production, and its manufacturing release at least $5-7 \%$ of $\mathrm{CO} 2$ emission [7]. Point out that $1 / 8$ of $\mathrm{CO} 2$ emission produced derives from cement [8]. Based on the viewpoint of carbon absorption, the benefit of employing logs as construction resources can implicate long-term carbon captivation [4]. Wood application in household furniture can reduce $\mathrm{CO} 2$ emissions because it consumes less energy in the manufacturing process and functions as carbon storage means [9].

Cempaka is categorized into only wood types in North Sulawesi. Despite its quantity decline, cempaka is one variety dominating forest stand structures in North Sulawesi. Rumoong Atas is a village in Tareran District, Minahasa Selatan Regency closely related to cempaka plants. Its public has long exploited cempaka timber as house and furniture construction resources. However, intervention in this process, such as reference to cement, steel, plastic and other materials in houses and furniture production, attract more particular attention to employing cempaka persistently by the people of Rumoong Atas. This study aims to uncover detailed information regarding cempaka practices carried out by the villagers in Rumoong Atas. The study findings are expected to be valuable as essential resources in organizing sustainable development strategies for the final result of cempaka wood species to contribute to the global warming issue.

\section{Methods}

This study was carried out in July 2020 in Rumoong Atas Village, Tareran District, South Minahasa Regency. The research sample was part of the population of Rumoong Atas Village, in which the sample employs purposive by selecting 40 respondents. Data collected was premier and secondary data. The type of primary data used in this research is qualitative data. Qualitative data is data in research that explains a phenomenon based on things that generally cannot be calculated. At the same time, secondary data is data from search results of official reports and data on official institution websites. In data collection, this research employed observation techniques, interviews with questionnaires, literature and documentation reviews. Several significant questionable matters were related to the usage and duration method of cempaka woods performed by the residents in the research region and the intention underlying the employment of these woods. The method used in this study was a descriptive method based on interview and field survey outcomes.

\section{Result and Discussion}

Generally, cempaka woods have been used by the people in North Sulawesi as raw materials to fabricate furniture, cupboards, and doors [10]. Established from interview outcomes recapitulation towards respondents in Rumoong Atas, it is evident that there are 
diverse usage approaches implemented (Figure 1). The most leading ones are as materials for household windows (30\%); doors (23\%); cupboards (15\%); tables (35); and chairs $(12 \%)$. Additionally, its primary use for housing remains customary for the people until the present day.

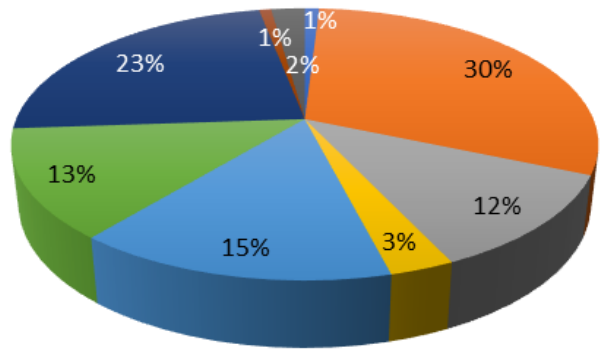

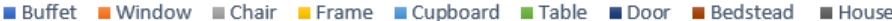

Fig. 1. Varieties of Cempaka Woods Usages by the Residents in Rumoong Atas Village.

Diverse cempaka wood uses instigated by the residents in Rumoong Atas Village may display the level of the public's requests toward the wood itself. The citizens have held psychological attachment values with cempaka wood since earlier times. Rumoong Atas Village is an old village in Minahasa Selatan located on higher ground. The isolation in the past resulted in the community's independent efforts to fulfil its basic needs, including building houses and furniture. Generally, the people of Minahasa have resided around cempaka stands. This situation is a preserved wisdom because cempaka plants obtain authentic aroma, which is believed to provide serenity. According to a study carried out by Graafland, it is found that Sub-ethnic Tongkimbut is one of the three primary sub-ethnic communities of Minahasa ancestors settling near the Pinawetengan Tumaratas stone region [11]. Since long ago, these societies have dwelled in the Cempaka Wasian forests, later known as Tombasian.

Based on Figure 1, it is clear that cempaka wood usages dominate more in house part constructions, especially for windows and doors. Nevertheless, the percentage of cempaka as core materials for houses is relatively insignificant. Although it is counted using its application volume, the result will depict minor differences in values. Modernity in housing applying more permanent means (stone and cement walls) becomes influential factors towards the exclusive use of cempaka wood as the key source in the making process of wooden houses. However, many people in Rumoong Atas still utilise cempaka to fabricate household equipment such as cupboards, tables, and chairs. Moreover, a few of them use it in buffet and bedstead productions.

The Minahasa people have practised cempaka wood for a long time. The interview outcomes regarding the period of consumption cempaka by the inhabitants of Rumoong Atas is illustrated in Figure 2. Based on the results, it is apparent that the public has utilised cempaka since more than 51 years ago. Some respondents state that occupied wooden houses are inherited from their parents built around 80 years ago. Inside the houses, there are still usable tables, chairs, and cupboards which are still functional for more than 60 years old. 


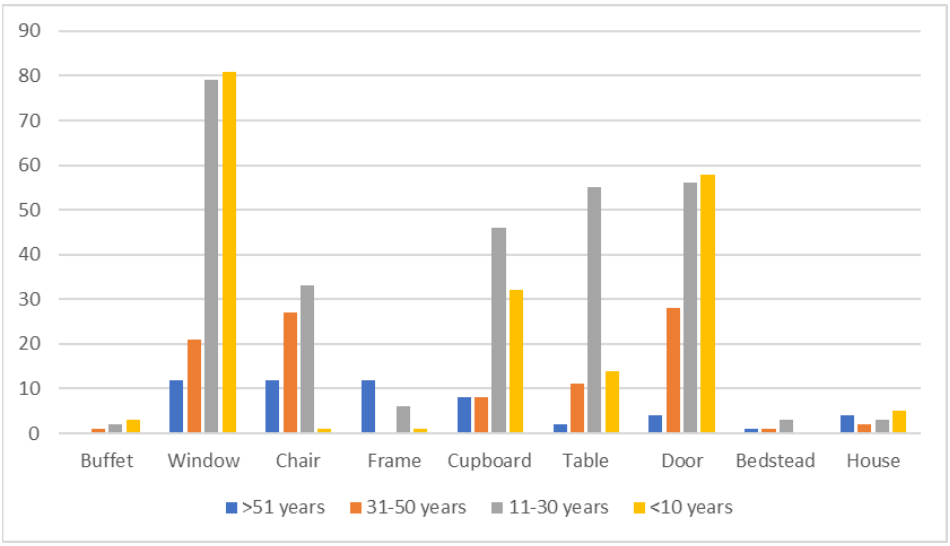

Fig. 2. Cempaka wood usage period by the people in Rumoong Atas Village.

Based on the second Figure, it seems that using cempaka wood as household tools (tables, chairs, and cupboards) have decreased in the past ten years. The comparison of these purposes with the previous period $(11-30$ years $)$ shows noteworthy dissimilarities. Certain presumed aspects affecting this decline are furniture made of different wood varieties, such as Jati from Java Island, with unique shapes and patterns. Apart from this, most people have started purchasing more modern equipment made of plastics and other materials from furniture stores.

Unlike furniture, windows and doors fabrications using cempaka logs gain popularity compare with preceding periods (Figure 2). Even though numerous new buildings are not made of cempaka in Rumoong Atas, the community still maintain a strong connection with this wood by using it as interior appliances. Some consider constructing houses with cempaka timbers attain more expensive economic value, although prestigiously cempaka wooden houses hold a higher value than stone houses. Economic values in building houses with cempaka woods are more significant if the consumers do not own cempaka itself. The majority of Rumoong Atas residents employ cempaka raw materials from replanted and inherited farmlands. Building by purchasing the timbers is assumed to be the reason causing changes in the assumption of high economic values in constructing wooden houses from cempaka woods.

The community of Rumoong Atas embraces the fundamental background in realizing cempaka woods. Recapitulation outcomes of factors affecting consumers in practising cempaka wood in daily lives are demonstrated in Figure 3.

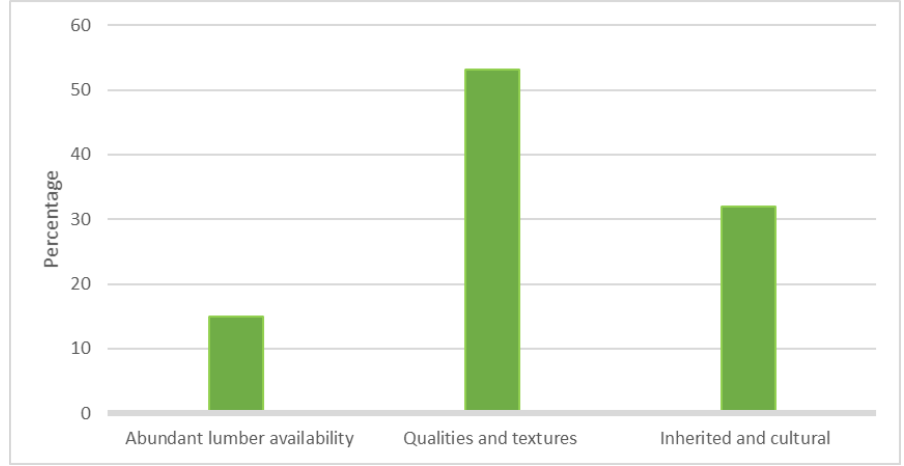

Fig. 3. Factors of Cempaka Wood Usages by the People of Rumoong Atas. 
Based on Figure 3, it is clear that the community's primary reason in Rumoong Atas's realization acts of cempaka wood is connected to its excellent qualities and textures. In addition, wood is widely famous for having fine qualities. This can be proven from its uses as the material for houses and furniture amongst specific individuals since many years ago until the present day the quality is still excellent (Figure 2). States that cempaka is a wood variety categorized into durable II and class strength III with the weight type $0.41-0.61$, wood density $400-500 \mathrm{~kg} / \mathrm{m} 3$ [12]. Apart from the wood quality, people prefer cempaka because of its natural texture. The older the plants are, the more visible the textures are.

Another motivation is linked to inherited practices and cultural connections. Cempaka embraces resilient historical importance with the culture of North Sulawesi society because it has long been consumed as primary raw materials for traditional houses of Minahasa [13]. Further, it is utilized sustainably by the people of Rumoong Atas. Parents advise next generations to endure cempaka woods because these are the essential materials for traditional wooden houses and traditional musical instruments (kolintang) of Minahasa. In the formal house construction process, according to the tradition of Tombulu region (one of Minahasa tribes), cempaka wood is the most common cut down plant. Moreover, mention that cempaka was the theme of Traditional Pinawetengan Festival (a cultural festival and traditional ceremony of Minahasa) in 2010 with the title "With the spirit of Mapalus (teamwork), together we can preserve and develop Cempaka Wood potential in Minahasa to prosper the people of North Sulawesi" $[14,15]$.

Abundant lumber availability is the last reason expressed by the people of Rumoong Atas to determine Cempaka woods. The conveniences in acquiring these logs encourage more people to select Cempaka instead of different planks. Cempaka has been known as the primary former of the community's forest structures in the Rommong Atas region for ages. Since earlier times, people have been cultivating cempaka plants, either monocultural or agroforestry systems, in maintained farmlands. The customs of replanting harvested plants grow into sustainable doings. Individuals of Rumoong Atas grasp wisdom in managing plot lands, and cempaka plants will be prioritized and planted on the soils which obtain sloppy topography rather than other plant varieties.

Drawing from the discussion result above, it is found that cempaka usages by the community of Rumoong Atas are well sustained. Despite the reduction in certain products, the public is still firmly attached to this wood type. One determination that must be enhanced to re-develop the public's interests is providing training spaces to local artisans to advance their capabilities in manufacturing household equipment from cempaka lumbers. Therefore, the competitiveness levels with other products in markets can be elevated.

The utilizations of cempaka wood in daily lives implemented by the public have affected the existence of cempaka plants in this region to be maintained continually. Indicate that the width of cempaka public forest in Tareran District is 1000 ha, known as the "Rumoong- Lansot" community [16]. Massive usages will advance the public's interests to repetitively cultivate the survival of cempaka plants in retained plot lands. More broadly, the development of cempaka plants by the people of Rumoong Atas village is expected to replace natural forests in North Sulawesi, which remain plummeting in both quality and quantity. By KLHK data, it is learned that in 1984, the initial stipulation, the width of forest areas in North Sulawesi was 936,801.59 ha.

Nonetheless, as time went by, the areas continued to narrow until today (Table 1). In addition to size constriction, the forests' condition in North Sulawesi coped with the decline of vegetation area due to past unsustainable management practices. Forest Watch Indonesia (2011) designates that deforestation occurred in forest areas in North Sulawesi from 2000 2009 around 83,117.16 ha. 
Table 1. The Width of Forest Areas in North Sulawesi.

\begin{tabular}{|c|c|c|c|c|c|}
\hline \multirow{2}{*}{ No } & \multirow{2}{*}{ Forest Function } & \multicolumn{4}{|c|}{ The Width of Forest Areas (Ha) } \\
\cline { 3 - 6 } & & TGHK/1984 & SK.452/1999 & SK.434/2013 & SK.734/2014 \\
\hline 1. & KSA/KPA & $227.869,01$ & $316.880,20$ & $315.064,86$ & 314.965 \\
\hline 2. & HL & $159.723,54$ & $182.564,48$ & $161.808,83$ & 161.784 \\
\hline 3. & HPT & $369.868,53$ & $216.833,48$ & $208.924,58$ & 208.927 \\
\hline 4. & HP & $83.516,85$ & $66.705,40$ & $64.559,83$ & 64.367 \\
\hline 5. & HPK & $95.823,67$ & $15.429,82$ & $14.701,31$ & 14.696 \\
\hline \multicolumn{2}{|r|}{ Total } & $936.801,59$ & $798.413,39$ & $765.059,41$ & 764.739 \\
\hline
\end{tabular}

Remarks: KPA/KSA = Nature Conservation Area/Nature Reserve Area; HL = Protection Forest; HPT $=$ Limited Production Forest; HP = Production Forest; HPK = convertible production forest (Source: BPKH VI Manado, 2014)

Cempaka Public's plantations that are well managed in the Rumoong Atas area are anticipated to contribute to the problem regarding the accessibility of woodland areas as environmental condition optimiser in the region of North Sulawesi. Similarly, mention that a well-maintained community's woodlands can function as the replacements for national forestry declining quantities and qualities [17].

Furthermore, this public's forests in Rumoong Atas will influence critical plot lands in North Sulawesi. BPDASHL Tondano states that critical plot lands in North Sulawesi intensify each year (Table 2). The most crucial quantity of additional critical plot lands is from outside forest areas. Critical land is soil that has experienced destruction resulting in the potential loss or reduction until the specified or expected period limit. Certain aspects causing the amplification of critical plot lands in North Sulawesi are assumed to be the presence of land purposes conversions to accelerate the growth of economic developments.

Table 2. The Width of Critical Plot lands in North Sulawesi.

\begin{tabular}{|c|c|c|c|c|}
\hline \multirow{2}{*}{ No } & \multirow{2}{*}{ Area } & \multicolumn{3}{|c|}{ The Width of Critical Plot lands (Ha) } \\
\hline & & 2013 & 2018 & 2020 \\
\hline 1. & Forst & 87.895 & $108.221,68$ & $128.061,84$ \\
\hline 2. & Non Forest & 181.316 & $181.560,32$ & $194.431,34$ \\
\hline & Total & 269.211 & 289.782 & $322.493,18$ \\
\hline
\end{tabular}

Source: BPDASHL Tondano, 2020

The demand for cempaka wood is increasing each year. This is due to massive requests in the traditional wooden house of Minahasa, whether from domestic markets or exports. Unfortunately, the insufficient availabilities of cempaka wood are imbalanced to the requests [18]. Emphasise that utilising wood in the Traditional House of Minahasa Industry is undergoing alteration in determining the wood varieties, unlike when Cempaka wood was commonly preferred [19]. Raw supplies from cempaka woods are increasingly challenging to acquire because the sources in natural timberlands are inadequate [20]. The potential of natural forestry in North Sulawesi as the merchants of logs and sawn timbers from North Sulawesi plantation attenuates each year persistently. (Table 3)

Table 3. Wood Production in North Sulawesi.

\begin{tabular}{|c|c|c|c|c|}
\hline \multirow{2}{*}{ No } & \multirow{2}{*}{ Type } & \multicolumn{3}{|c|}{ Wood Production in North Sulawesi $\left(\mathbf{m}^{3}\right)$} \\
\hline & & 2014 & 2015 & 2016 \\
\hline 1. & Log wood & 2.580 & 1.613 & 450 \\
\hline 2. & Sawn timber & 2.866 & 1.705 & 476 \\
\hline & Total & 5.446 & 3.318 & 926 \\
\hline
\end{tabular}

Source : BPS North Sulawesi, 2021 
Sustainable survival of cempaka public's forests in Rumoong Atas is one of the acts that can be realized to avert obstacles associated with insufficient cempaka woods and reinforce the endurance of natural forests that are declining and minimizing the size of critical plot lands in North Sulawesi. Point out the excellent benefits of cempaka plants and their dropping population in natural habitats should be the foremost motives to cultivate these plants, particularly in farmers' lands in the form of public's forests [21].

In its association with global warming, cempaka plants in Rumoong Atas are estimated to contribute to mitigation acts towards climate change. Likewise, mention that emission reduction in the materialization stage lies on source preferences. This reduction can be achieved more easily by lessening clay bricks, steel, concrete, calcium, cement, and other materials containing significant carbon emissions [1]. Low-carbon means such as wood condenses a vast amount of carbon emission [22].

\section{Conclusion}

Various usages of cempaka woods are found within the people of Rumoong Atas Village. Many individuals employ cempaka as critical materials for tables, cupboards, chairs, bed frames, doors, windows, and even wooden houses. The villagers decide on cempaka timbers for specific reasons such as hereditary practices \& the level of cultural and historical attachment, outstanding wood quality and authentic texture, and accessibilities. These diverse functions implicate the abundant existence of cempaka plantations around Rumoong Atas. Since many years ago, the residents have cultivated cempaka either monoculturally or by agroforestry systems in conserved farmlands. This survival needs to be maintained and advanced constantly. Cempaka plants cultivation by the community of Rumoong Atas Village is anticipated to support the survival of natural woodlands in North Sulawesi that are plunging in quality and quantity and the impact on the addition of critical land areas. Furthermore, in its relation to the global warming issue, cempaka plant existence is projected to support the world mitigation acts towards climate change matters.

\section{References}

1. Li, H., Luo, Z., Xu, X., Cang, Y., \& Yang, L. Journal of Cleaner Production, 303:114, (2021).

2. Quere, C, L., Andrew, R, M., Friedlingstein, P., Sitch, S., Hauck, J., \& Pongratz, J.Earth Syst. Sci. Data, 10.4:2141- 2194, (2018).

3. Sulkhan, M. Pemanasan Global dan Masa Depan Bumi. Alprin. (2019).

4. Hung, C. P., Wei, C., Wang, S. Y., \& Lin, F, C. Renewable Energy 34:1896-1901, (2009)

5. Wang, S, Y. Chinese Wood Structure Association, 65-81, (2009).

6. Liu, Y., Zhang, J, X., Zhou, B, G., Huang, Z, Z. (2005). Jiangsu Architecture 3:5-8, (2005).

7. Taylor, M., Tam, C., \& Gielen, D. Energy Efficiency and CO2 Emissions from the Global Cement Industry. Energy Technology Policy Division, International Energy Agency (2006).

8. Hao, L, X., Zhao, F, Q., \& Zhao, P, X. Advanced Materials Research, 233-235:412415, (2011).

9. Gustavsson, L., Pingoud, K., \& Sather, R. Mitigation and Adaptation Strategies for Global Change 11:667-691, (2006). 
10. Kinho, J., \& Mahfudz. Prospek pengembangan cempaka di Sulawesi Utara. Manado: Balai Penelitian Kehutanan Manado, (2011).

11. Wenas, J. Sejarah perkembangan Ma'zani. Makalah disampaikan dalam seminar seni budaya di Taman Budaya Manado, (2007).

12. Langi, Y, A, R.. Model Penduga Biomassa Dan Karbon Pada Tegakan Hutan Rakyat Cempaka (Elmerrillia ovalis) dan Wasian (Elmerrrillia celebica) di Kabupaten Minahasa Sulawesi Utara. Thesis Sekolah Pasca Sarjana Institut Pertanian Bogor. Bogor, (2007).

13. Irawan, A., Hidayah, H, N., Iwanuddin, Kinho, J., \& Halawane, J, E. Indonesian Journal of Forestry Research, 7.2:113-120, (2020).

14. Lumempouw, F.Proses pembuatan rumah menurut adat di daerah tombulu. Kajian Komunikasi Adat dan Budaya Baharipp. 117-130. ISSN 978-19365-0-4, (2014).

15. Arini, D. I. D., \& Tabba, S. Upacara Adat Pinawetengan Simbol Kepedulian Kelestarian Alam dan Budaya Sulawesi Utara. Majalah Kehutanan Indonesia. Edisi I Tahun 2011 ; 37-39. Jakarta. Kementerian Kehutanan,(2011).

16. Ngangi,J., \& Pelealu, J. A survey of the termite subterranean (isoptera) of an cempaka-wasian plantation in South Minahasa District, North Sulawesi, Indonesia. Buku prosiding Seminar Nasional Inovasi Hasil Penelitian Pendidikan dan Gagasan Kreatif, Tabanan, (2016).

17. Sukwika, T., Darusman, D., Kusmana, C., \& Nurrochmat, D, R. Biodiversitas. 17.1:241-248, (2016).

18. Sasmuko, S. A. Jurnal Penelitian Hasil Hutan, 28.3:278-290, (2010)

19. Rumengan, H, O., Sangkertadi, \& Wuisang, C, E, V. Media Matrasain, 12.1: 46-53, (2015).

20. Arini, D, I, D., \& Sidabutar. H. Completion report project ITTO PD 646/12 rev.3(F). Manado Environment and Forestry Research and Development Institute (MEFRDI) Research Development and Innovation Agency, (2020).

21. Yeny, I., Murniati, \& Octavia, D. Jurnal Penelitian Hutan Tanaman, 14,1:35-49, (2017).

22. Huang, L., Liu, Y., Krigsvoll, G., \& Johansen, F. J. Clean. Prod. 173, 151-159, (2018). 